\title{
Minder fra Tandslet Præstegaard paa Als 1850-1867.
}

\author{
Af A. P. Tuxen.
}

II.

Der var mange vakre Bondefamilier i Sognet; blandt dem, der kom hjemme, mindes jeg flere Medlemmer af de ansete Slægter Bonefeldt, Bladt ug Kaad, Vesti Esbensen, der var gift med en Bladt, og Jørgen Jacobsen, som havde været Rideknægt hos Hertugen af Augustenborg og var ham meget hengiven. Adskillige af dem har siden gæstet mine Forældre paa Sjælland, og jeg har vedligeholdt Forbindelsen med dem. Mine Forældre kom ofte med til Brylluper og lignende Festligheder, men kunde selvfølgelig ikke overkomme at omgaas alle Sognets Beboere privat; vi Børn kom mange Steder, hvor de ikke kom; vi deltog i Skolebørnenes Sommer- og Vinterballer, hvor Traktementet henholdsvis var Risvælling og Mælk og Strutter, og fejrede vore Legekammeraters Fødselsdage i deres Hjem; at de ogsaa mødte op hos os, er en Selvfølge. Hver Juleaftens Formiddag etablerede Fader i sin Stue en lille Butik, hvor vi for vore Sparepenge købte Legetøj og Billeder, som vi drog ud med og fordelte til vore smaa Venner. Da vi overalt blev trakterede med utrolig salte Ebleskiver og Mjød, og da vi ogsaa tog godt til os ved det hjemlige 
Julebord, var Julenat i Reglen ret urolig. "Jeg mindes med Glæde de Julepræsenter, Du og Dine Brødre lwar givet os; de er jo naturligvis forsvundne tillige med de glade Barndomsdage; men de vil forst sent forsvinde af min Erindring", skrev en af Legekammeraterne mange Aar efter; og endnu lever der gamle Folk, der mindes disse Julebesøg. Medens Børnene var ude, var der et stort Rykind i Præstegaarden af Kvinder, der modtog Gaver af Kød og Flæsk, Brød og Kager, Kolonialvarer, et og andet Klædningsstykke eller andre nyttige Ting. Moder udfoldede en stor Velgørenhed; mangfoldige var de Koner, der fik Lov til at hente en Krukke Mælk i Præstegaarden; hun lavede Sygemad og hjalp, hvor hun kunde. Hvorledes Forældrene fik Tid til at pynte det Juletræ, som vi aldrig maatte se, for paa selve Aftenen, er mig en Gaade; men pyntet blev det, og selv havde de lavet hele Juletræspynten og adskillige af Gaverne. Hvert Aar blev en Del af Pastor Berings lærde teologiske Bøger lavet om til Børnebøger, fyldte med de herligste Neu Ruppinerbilleder med Tekster, der var meget bedre end dem, "Blæksprutten" nu møder op med. De bestod af moralske Fortællinger eller kærnefulde Vers, snart spottende som:

Præsten og Hunden

Tjener deres Føde med Munden.

Snart melankolske som:

Er man først lagt under Mulde, Korset mer ej følge skulde.

Eller gaadefulde:

Trommen er dyr Musik, Skønt den ej til Hjertet gik. 
Ja! Gustav Kühn i Neu Ruppin havde virkelig en Kulturmission; hans Billeder fandtes i Præstegaarden og i den ringeste Hytte; hvert. Barn havde en hel Samling, der ved Konfirmationen blev udstykket og fordelt til dem, der blev tilbage i skolen. De Forsog, der blev gjort paa at fortrænge dem, mislykkedes uvægerligt; de danske Billeder var langt, langt bedre, men de manglede de tyskes selvglade Naivitet og barokke Farvesammensætninger.

Noget af det mest spændende ved Juleaften var Udpakningen af de københavnske Julekasser. Gaverne var i Reglen tarvelige; men enten de nu bestod i en Eske Tinsoldater, en Bliktrompet, en Træsabel, et Stykke ildelugtende Sæbe eller en Flaske med tvivlsom Parfume, gjorde de altid stor Lykke. Selve Juletræet var et levende Grantræ, taget ind fra Haven og anbragt med sin Jordklump i en stor Spand; efter Julen blev det sat ned igen og groede videre; saa kunde det i Fred og Ro tsenke paa den svundne Herlighed, og det med mere ublandet Glede end $\mathbf{H}$. C. Andersens "Grantræ«, der var rodløst. Det hele var en Art Værnepligt, der paahvilede Havens Graner; en Ende kulørt Uldgarn, en stivnet Draabe farvet Voks, fortalte længe efter, at det og det Træ havde "været indkaldt.«

Foran mig ligger der et Album med Portrætter af Sogneboerne, som i 1867 blev skænket mine Forældre, og ved Siden af et Uddrag af Folketællingslisten fra 1860; mange Ansigter og mange Navne dukker frem for Erindringen. I Forbifarten skal jeg nævne nogle enkelte. I en lille Aftægtsstue, hvis Vægge fra øverst til nederst var beklædte med brogede Billeder, boede Eleonore Margrete Lorenzen, der var fodt i Sonder- 
borg 1776; hendes Fortid er mig ganske ubekendt; jeg ved blot, at hun havde haft en Datter, der laa paa Kirkegaarden; jeg har kun kendt hende som et gammelt Fattiglem, der havde sin Gang i Præstegaarden. Naar vi Børn besøgte hende, spillede hun for os paa sin Harmonika, trippede, nikkede Takten til og sang Viser, hvis Tekst ikke var til at forstaa. Bournonville interesserede sig for hende, skænkede hende en pragtfuld Harmonika og skildrede hende for H. C. Andersen, der satte hende ind $i$ en af sine Romaner som "Musikant Grete«; mig inspirerede hun til mine første Vers, der dog lige saa lidt som min senere "Digtning“ horte ind under Lyrikken. Hun var en af de sidste $\mathbf{i}$ vor $\mathrm{By}$, der bar den ejendommelige Hovedbedækning, der dengang endnu var almindelig i Norreherred, og som nu kun kendes fra den staaende Figur i Illustrationen til "de sonderjydske Piger\%. Nationaldragten var lige ved at forsvinde; jeg mindes dunkelt to gamle Mænd med rød Tophue, gule Knæbenklæder, lange hvide Strømper og Træsko. "Gamle Grethe« døde 181;4; paa hendes Auktion købte jeg alle hendes Billeder for en Mark (33 Øre). Vor nærmeste Nabo, Jens Elley, var født omtrent 1822; han var lidt af en Tusindkunstner, tømrede, snedkrede loddede Bliktøj og reparerede Ure; han kunde ogsaa føre en Le og hjælpe med i Hosten i Præstegaarden; han endte som Høker og Beværter. Han var rig paa Vittigheder, Viser og Historier. der somme Tider var lidt saftige. "Uha! Uha! ikken ful Maand æ hær«, sagde hans smukke og elskværdige Kone, vor Avlskarl Peter Hansens Søster. Han skrev rigtig godt for sig; jeg besidder endnu adskillige af hans Breve. En anden Nabo var den aldrende Drejer Hans Nielsen, i daglig Tale kaldet Hans 
Svarrer (Svarver burde det nok hedde). Han var ogsaa Maler og lavede de Trækors og andre Gravmæler, som var i Brug, inden man gik over til at anvende Jærn, Marmor og Granit. Det var ganske kønne og dygtige Arbejder, men uden synderlig Afveksling; der fandtes næppe flere end 3-4 Modeller; ogsaa de sirlige Inkriptioner var meget ensartede:

Jeg saa den skjønne Lillie, Men ak hvor snart den visnede

Med sine Yndigheder.

Som Blomstens Yndigheder

Bortsvinde Livets Glæder «.

Ak ja, der var mange unge Piger, der døde af Tæring! Naar Hans Svarrer skulde puste lidt, gik han med Hænderne paa Ryggen gennem den langstrakte Have, der endte $i$ en lille $\mathrm{H} ø j$; her standsede han, saa sig om og udtalte sin Mening om Vejret: "De' er et apagtigt lækkert Vær e Daw«. Denne Bedømmelse kunde ogsaa et imponerende Tordenvejr faa. Dorthe, hans Kone, havde et uhyre surt Ansigt; hvor kunde hun skælde, naar vi Nytaarsaften slog en Jydepotte itu paa hendes Dør! Nej saa var Krokonen, Snedker Rigelsens Enke, ganske anderledes mild; hun vilde gerne kysse mig, der virkelig var en pæn lille Dreng; men det kostede mange Svedsker. Jeg blev iovrigt stukket ud af en fynsk Malersvend, der gav Danselektioner paa Kroen; han ægtede den adskillig ældre Madame Rigelsen og blev Kromand; men han passede ikke Bedriften; det gik tilbage, og det endte ret daarligt for Parret. Der blev danset meget paa Kroerne, og det' var ikke altsammen af det gode; men værre er det blevet, efter at Cyklerne har gjort det 
muligt at deltage i Kroballerne i en uhyre Omkreds.

Men nu tør jeg ikke tegne flere Portrætter, skønt der var mange, der godt kunde fortjene at tages med; der er mange Mænd og Kvinder, hvis Navne jeg bevarer i venlig Erindring: Johan Christensen i Holballe og hans begavede Hustru; Nicolai Nicolaisen og $\mathrm{Hu}-$ stru, hvis 80-aarige eneste Søn og Svigerdatter endnu horer t:1 mine Venner*), Christian Bladt paa Tandsgaard, der forst dode 1923, henved 90 Aar gammel, med hvis Efterslagt jeg staar i Forbindelse, Hans Iversen i LErtebjerg og mange, mange flere. Der er jo ogsaa dem, der ikke mindes for deres Dyders Skyld; men gennemgaaende var Sognebornene brave og hæderlige Folk; der var ikke megen haablos Fattigdom og kun faa professionelle Drukkenbolte. En af de mere ondartede hedJørgen Hannes; men han vidste godt, at det var galt fat med ham; da jeg som en høflig lille Dreng hilste paa ham, sagde han: "Tag ikke Hatten af, før Du ser Manden«; et andet Bevis paa hans Selvkritik var, at han hængte sig. Jeg ser endnu Fysikus Mathiesen fra Sønderborg slange det kriminelle Reb henad vort Spisebord med et Udbrud af den for ham ganske ejendommelige Latter. Len forsorne og fordrukne Københavner Hallgren, hvis Navn sikkert endnu mindes af mange, boede i Lysabild, men huserede ogsaa i Tandslet; han opholdt sig meget over sin Præstekone, Fru Bendz, der forgæeves søgte at omvende ham.

Mine Forældre kom meget ud, og der kom mange hos dem. Middagsselskaber var sjældne; Aftensel-

* Jurgen Nicolaisen er dud, efter at disse Erindringer er skrevne. 
skaber var Reglen; ofte kom der hele Vognladninger af uanmeldte Gæster, men Husmødrene klarede altid Situationen glimrende. Jeg slaar op paa Maa og Faa i Journalen og finder for Oktober 1858; 7 . i Lysabild, 10. paa Maibølgaard med Augusta og 3 Drenge, 12. Besøg af Jessens og Schwensens, 15. hos Arnesens med Augusta, Fruens Fødselsdag; 17. til Middag hos Provst Hoeck med Augusta (Bispevisitats); 20. Præmiepløjning Middag hos Arnesens; 21. Bryllup i Jestrup; 22. Besøg af Henningsens og Børnene fra Maibolgaard; 23. Tante Eva og Charlotte (Moders Moster og Søster) ankom om Aftenen; 24. i Notmark med Augusta og Charlotte (Bispevisitats); 25. hos Arnesens med Augusta, Eva og Charlotte; 26. til Middag paa Maibølgaard; 27. stort Aftenselskab hos os selv; 31 i Asserballe med Augusta (Bispevisitats). Mrerkelig nok nævnes ikke Ulkebøl Præstegaard i den Maaned; det var ellers et af de Steder, hvor mine Forældre kom mest. Efter Krigen blev Kredsen snævrere; men de, der blev tilbage sluttede sig tættere sammen og mødtes hyppigere. I Januar 186; nævner Journalen følgende Sammenkomster: 2. i Lysabild; 5. i Hørup; 9. i Degnegaarden; 12. paa Augustenborg; 15. i Hørup med Augusta og Drengene; 21. i Lysabild; 22. i Sonderborg; 26. paa Gamnelgaard med Augusta og Drengene; 28. Pastor Bendz til Te; 30. Schwensens, Fangels og Møllers til Aften. Det var dog endnu et ganske respektabelt Antal.

Et Par meget elskvardige Naboer var Pastor Henningsens i Lysabild; de var langt ældre end de unge Præstefolk i Tandslet; han var født 1799, hun 1801; men saa meget bedre kunde de tage sig af dem og 
hjælpe dem med Raad og Anvisninger; de var tilmed begge fodte paa Øen. De var barnløse, men holdt meget af Børn; han var henrykt, naar Smaadrengene kælede for ham; jeg var hans Gudsøn og specielle Yndling. Destovæire blev han meget tidlig gammel; han var ikke fyldt de 60, da et apoplektisk Anfald gjorde ham til en sløvet, savlende olding; meget tunghør var han i Forvejen. Han maatte holde Kapellan, hvad der baade var ærgerligt og kostbart. En Dag, da han gik med Fader i Frugthaven, hvor Kalkuneme sogte deres Fode mellem Træerne, sagde han: "Kap.. Kapellanerne de æder Græs«. Hvad Hjertet er fuldt af, lober Munden over med; men Tungen slog jo Sludder. I $181 ; 0$ tog han sin Afsked og flyttede til Augustenborg, hvor han døde 1866; han havde da været Enkemand i \& Aar. Hans Eftermand, Pastor Bendz var fint dannet og meget belæst, men altid meget bekymret for sit Helbred; han og hans noget ældre Hustru, der havde været meget smuk, var Kobenhavnere; de havde en eneste Son, der var meget xldre end vi, og som kun var hjemme.i Ferierne; der var altsaa ikke morsomt i Præstegaarden i hvert Fald ikke for raske Smaadrenge; vi kneb derfor gerne over i Degnegaarden, hvor der var Børn i lange Baner; den ældste af Sonnerne var ganske vist paa $\mathrm{Al}-$ der med Moder, men den yngste var kun 4 Aar ældre end jeg, og han, hans Moder og Sostre modtog altid os Smaafyre med storste Elskværdighed; Fru Becker lavede de dejligste.Ebleskiver, og af og til fik »Tuxens Drenge" direkte Indbydelse. Beckers, der selv var dygtige Folk, havde megen Glæde af deres Born; de 3 Sonner blev alle Lærere, de 2 ældste af dem lod sig ikke nøje hermed, men studerede trods de dermed 
forbundne Vanskeligheder videre og blev Præster; en af Dotrene hørte til det første Hold af eksaminerede Almuelærerinder. Den yngste, af Sønnerne, Peter, døde 1920 som Overlærer ved Kommuneskolen og Forstander for den tekniske Skole i Skive; da jeg som kommanderende General boede i Viborg, genoptog jeg Forbindelsen mєd Barndomskammeraten, og vi havde megen Glæde af at forny de gamle Minder. I Jylland traf jeg ogsaa den ældre Broder, Ernst, der var Præst i Dronninglund i Vendsyssel. I Maj 1924 fejrede han paa Frederiksberg sammen med sine Born og 2 næsten lige saa ganle Søstre, rask og aandsfrisk, sin 90 Aars Fødselsdag; han har udfoldet en ikke ringe Virksomhed som Skribent og har navnlig udgivet nogle gode "Erindringer«, der jo gaar henved en Snes Aar længere tilbage i Tiden end mine.

Præstefamilien i Hørup, Tandslets vestlige Nabosogn, kunde næsten betragtes som et Dynasti. Pastor Christian Schwensen, der var bleven Sogneprast i 184ti, havde overtaget Embedet efter sin Fader, der havde beklædt det siden 1795. Selv var han fodt i Præstegaarden 1811, blev 1838 personel Kapellan hos sin Fader og tog først sin Afsked 1893. Af hans Søstre var en gift med Biskop Hansen, en anden med Proprietær Jessen paa Maibølgaard, en tredie med Pastor Fangel i Notmark; af disse Familiers Born blev mange gifte paa Als, og "den store Familie" blev efterhaanden en talrig og indflydelsesrig Slægt. Af dens Medlemmer forblev de fleste paa Øen efter Afstaaelsen og blev gode Stotter for Danskheden, skønt Præsterne naturligvis maatte optræede med stor Forsigtighed. Et Par af Pastor Schwensens Brødre havde som unge Mænd nedsat sig i Christiania, hvor de blev 
dygtige, ansete og meget rige Forretningsmænd; en Gade $i$ den norske Hovedstad barer endnu deres Navn. Da de ikke efterlod sig Afkom, blev "den store Familie«, der arvede dem, i Tiden ret velstaaende, hvad der yderligere støttede dens Stilling.

Med Schwensens sluttede mine Forældre et varigt Venskab, der endnu vedligeholdes af de faa af deres Børn, der er i Live. Moder og Pastor Schwensen var begge fødte den 23. Marts, men der var 20 Aar mellem dem; Journalen udviser, at der ofte var Formiddagsselskab i Tandslet og Aftenselskab i Hørup paa den fælles Fødselsdag. Han var en høj, svær Skikkelse med meget udprægede Træk, en dygtig Præst, en god Taler, i Besiddelse af meget Lune; han var i hoj Grad knyttet til sin Fødeø, sin Menighed og først og fremmest til sin Præstegaard, der laa i de skønneste Naturomgivelser, og kunde ikke trenke sig at bryde op, for Alder og Skrøbelighed tvang ham dertil. Hans første Hustru var allerede død 18s8; 1855 giftede han sig igen med en Datter af Provst Steffensen i Broager; hun var en lille, buttet, rødmusset, højst elskværdig Dame, en god Husmoder og en fortræffelig Værtinde for de talrige Gæster, der strømmede til det gæstfrie Hjem. Her holdt vi Drenge meget af at komme; og senere har vi alle haft den Glæde at præsentere vore Hustruer for vor Barndoms Venner. Ogsaa mine Forældre har paa deres ældre Dage aflagt længere Besøg i Hørup, ligesom Schwensens hal været Gæster i den sjællandske Præstegaard. Deres sidste Aar tilbragte de paa det gamle jydske Herresæde Trudsholm hos deres eneste Søn, og her døde den gamle Præst i 1899, medens hans 17 Aar yngre Enke overlevede ham til 1913. Aaret før hendes Død gæstede jeg hende $\mathrm{i}$ hendes hyggelige Hjem. 
Hos Bangs i Asserballe Præstegaard kom vi en hel Del; de var jævnaldrende med mine Forældre, kom omtrent samtidig med dem til Als og fik en hel Flok Børn, der passede godt til os i Alder; vi Drenge hyggede os dog aldrig i "det hvide Hus", var bange for Præsten og kom aldrig rigtig i Kontakt med Børnene. Den næestældste af Sonnerne var den senere saa bekendte Forfatter Herman Bang. Handlingen i hans ypperlige Bøger: "Tine« og "Det hvide Hus« foregaar jo paa Als; men hans personlige Kendskab til Forholdene paa Øen kan ikke have været indgaaende, da han kun var (; Aar gammel, da han Aaret for Krigen 181;4 rejste med sine Forældre til Horsens; indfødte Alsingere er heller ikke rigtig tilfredse med hans historiske Romaner, hvis man kan kalde dem saaledes. Han var nu alligevel tidligt udviklet, og jeg husker, at han overfor mig udtalte sin Forargelse over, at den nye Præst i Asserballe, den halvgamle, barnløse Enkemand, Pastor G. V. Müller, skulde ægte en ganske ung Pige; det nye Kuld Born, der fødtes i sdet hvide Hus", blev imidlertid livskraftigere end det forrige; i 186 if kom den nu saa navnkundige I. P. Müller til Verden; hans "Systemı har gjort endnu storre Lykke end Herman Bangs Romaner, og hans Boger er oversatte paa 25 Sprog; det er sikkert taknemligere at tage sig af Menneskenes Krop end af deres Aand. Herman Bang og alle hans, Søskende er forlængst døde; men Systemets Opfinder bliver sikkert udødelig.

Den betydeligste Personlighed blandt de alsiske Præster var Sognepræsten til Egen, Biskop over Als og Erø, Jørgen Hansen, en Smedeson fra Tandslet. Hans Erindringer foreligger i disse Aarbøger, Aar- 
gang 1904, og hans Levned er udførlig skildret $\mathbf{i}$ vore biografiske Leksika. Hans Børn var meget ældre end jeg, og som Dreng har jeg aldrig været i Guderup Præstegaard; som voksen har jeg flere Gange været Gæst hos det statelige Par og haft længere Samtaler med Bispen, som havde indgaaende Kendskab til sønderjydsk Administration og Lovgivning; han var en udpræget "dansk Slesviger", og hans Forbliven $\mathbf{i}$ Embedet efter Krigen var af stor Betydning for Danskheden, hvis Fjender havde megen Respekt for den kraftige Prælat. Til dem hørte Provst Hoeck i Kettinge, der var tyskdannet og tysksindet, en Slesvigholstener af det reneste Vand; mellem Krigene holdt han sig i Skindet; han mønstrede engang Drengeflokken i Tandslet Præstegaard og udbrød: "De skal værne om Fædrelandet«, men vi troede ham ikke; en gammel Bonde fortalte mig i 1920, at han kunde huske, at Præstens Drenge kom stormende ud og raabte: "Vi vil ikke være hos den tyske Rau!« Efter 1864 kom Kløerne frem, og han blev Preussernes nidkære Tjener. Den første, det gik ud over, var Pastor Krog-Meyer i Ulkebøl, der meget hurtigt blev fjernet; han havde i sin Tid været Lærer for de hertugelige Børn, men havde brudt med Augustenborgerne, da de stillede sig i Spidsen for Oprøret, og det maatte han nu bøde for. Mine ForæIdre kom meget hos det gæstfrie, men barnløse Par; de var ogsaa ofte Gæster hos os; han holdt meget af en L'hombre, og vore gamle Spilleborde bærer Spor af den Kraft, hvormed han førte Regnskabet. Selv har jeg aldrig været $i$ den smukke, fra begge Krigene saa bekendte Præstegaard. Til Gengæld kom vi Børn ret ofte i Notmark hos Pastor Fangels, hvis yngste Søn, Holger, 
var jævnaldrende med mig. Saa vel Præsten som begge hans Hustruer, var indfodte Alsingere; derimod var Pastor Bernth paa Kegnæs fra Kongeriget; hans Hustru var dog født paa Als. En Rejse til Kegnæs var meget interessant, da man i Reglen sejlede over Høruphav; skønt Bernths var barnløse, vilde vi gerne besøge dem; de blev paa Als mange Aar efter Krigen ligesom Bendz i Lysabild, der endog døde i Kaldet.

En stor Del af Faders Besog, baade inden- og udensogns, foregik til Fods, og, naar Drengene var bleven 4-5 Aar gamle, tog han dem gerne med; det var fornøjelige og lærerige Ture; vi lærte mange Mennesker at kende, og Fader fortalte os meget, som vi havde Nytte og Glæde af at vide. Den halve Milsvej til Lysabild eller til Hørup tilbagelagdes med Lethed; noget større Fordringer stillede Marchen til Augustenborg, der var dobbelt saa lang; men saa var Turen ogsaa meget lonnende. Her boede nemlig en hel Del Familier, der hørte til mine Forældres Omgang. I de forste Aar nævner Journalen hyppigt Overinspektør Hornemann, hvem Administrationen af de hertugelige Godser m. m. var overdraget; han døde imidlertid allerede i 1858, og jeg mindes ham kun dunkelt. Bedre husker jeg Kaptajn Schlegel, der samme Aar blev forsat fra Augustenborg; men han havde ogsaa røde Striber ned ad Benklæderne, og jeg syntes det var morsomt at kravle op ad hans Ben; hans musikalske Hustru erindrer jeg ogsaa; hun spillede firhændigt med Moder og sang Duetter med Fader. Han gik hele Livet igennem under Navnet "afdøde Schlegel«, fordi han i Reglen blev anvendt paa afsides beliggende Steder: Augustenborg, Rønne, 
Frederiksværk, Trekroner og Hærens Laboratorium, hvis Chef han var, da han i 1889 tog sin Afsked. Han var ellers levende nok og var en dygtig Officer, hvem jeg lærte at sætte Pris paa, da jeg selv var indtraadt $i$ Hæren. Mine Forældres nærmeste Venner var vel Herredsfoged Arnesen og hans nydelige og elskværdige Frue; de havde et Par Børn, en noget ældre Søn, der blev en bekendt og anset Landbrugskonsulent, og en Datter paa min Alder, der døde 10 Aar gammel. Mit forste Gækkebrev var fra hende. Arnesens boede paa "Palæet«, hvor ogsaa Kontoreme og Arresterne befandt sig; han var en meget anset Dommer og Politimester, der efter Krigen meget snart fandt Anvendelse i Kongeriget. Ogsaa hos Hornemanns Efterfølger, Kammerraad Weilbach, senere Amtsforvalter i Randers, gift med en Datter af den kommanderende General fra 18:8, Hedemann, var der jævnaldrende Børn, ligesom paa Apoteket; men begge Steder var det "kun" Pigebørn; Sønnerne fra Apoteket, den senere Oberst C. Gjernals og Overretssagfører Børge Jacobsen, var en Del yngre end vi. Da Apoteker Jacobsen var ene paa Apoteket, kom han aldrig udenfor sit Hus og sin dejlige Have, der skraanede ned mod Fjorden; vi saa dog ofte ind til dem, og med Børnene kom vi jævnlig sammen. Da han blev gammel, solgte han sit Apotek og flyttede til Fredensborg, hvor jeg tidt har besøgt ham og hans smukke elskværdige Frue, f. Gjern. Hos Kammerraad Fengers paa Herregaarden kom vi ikke; men af de talrige Børn hørte de yngste til vore Legekammerater, hvem vi ofte traf sammen med hos andre. Der fortælles, at Familien ankom til Øen paa et Skib, ladet til Rælingen med Voksne og Børn, Kreaturer af alle Slags, Møbler og Inventar, en rigtig 
Noas Ark. Den Familie paa Augustenborg, som jeg kom nærmest, var den Ahlmannske. Den senere saa bekendte sønderjydske Patriot og Politiker, Nicolai Ahlmann havde i 1861 kun 52 Aar gammel bortforpagtet sin Gaard, Werthemine og købt det smukke Hus, som Hofpræst Jessen i sin Tid havde bygget; jeg har allerede omtalt, at hans yngste Søn i et Par Aar levede sammen med os i Præstegaarden; hans yngste Datter ægtede i 1873 min Morbroder, Læge E. Bournonville. Ved sin anden Svigersøn, Forpagter Sophus Hansens Død, maatte Ahlmann overtage Sønderborg Ladegaard, og her lærte min Broder Landvæsenet i 1871-72. Hans Liv og Virksomhed er denne Aarbogs Læsere saa bekendt, at jeg ikke skal dvæle derved; jeg skal kun omtale, at han og hans Hustru, født Dons, fra 1875 til hans Død 1890 havde deres Hjem paa Frederiksberg; det stod aabent for alle Alsingere, og her traf jeg ofte Landsmæend.

Augustenborgs største Attraktion var det aarlige Krammarked, som vi Børn glædede os til længe i Forvejen. Det lignede alle andre Markeder i Landet og jeg skal ikke opholde mig længe ved det; kun maa jeg fortælle, at jeg der for første Gang hørte "Sangerinder"; det var i Kroens, nu Slotshotellets store Sal 1866; jeg kan endog huske følgende Vekselsang:

"Wir fragen Sie.

Was sagen Sie?

Dass ohne Liebe und ohne Sonne

Dass ohne Liebe man nicht leben kann«.

Og det kan der være noget om! Nok er det; næst efter Tandslet holder jeg mest af Augustenborg, hvor jeg gerne opholder mig nogle Dage hver Sommer sam- 
men med ikke saa faa gamle Venner og Bekendte, der tilbringer deres Alderdom paa dette skønne Sted.

Af Herregaarde fandtes paa Als kun de tidligere hertugelige Avlsgaarde, der efter Krigen blev Statsejendom og i Løbet af 50'erne for en stor Del solgtes til Forpagterne, som i Reglen stod sig godt ved at overtage dem. Ingen af de nye Proprietærer førte stort Hus, men levede ganske som Præstefamilierne; deres Boliger var heller ikke videre herskabelige. Ejeren af Majbølgaard, Hans Heinrich Jessen, havde i 1847 overtaget Forpagtningen af Fødegaarden efter sin Fader. Han var gift med Pastor Schwensens yngste Soster. Parret, der var jævnaldrende med mine Forældre og havde en Del Børn, der i Alder passede godt med os, horte til vore gode Venner. Han var en dygtig Landmand af den gamle Skole, en livlig Fortæller med et ejendommeligt tørt Lune, men iøvrigt ret prosaisk; hans elskværdige, men noget svagelige Hustru var mere poetisk anlagt. Gaarden er bevaret $i$ slagten og ejes nu af en Sønnesøn. Familien Jessen har uden at spille en fremtrædende politisk Rolle været Dansklieden en god Stotte; jeg har stadig staaet i Forbindelse med den; der er ikke mange, med hvem jeg bedre kan drøfte gamle Minder end med H. H. Jessens ældste Datter, der bor paa Augustenborg. Ejeren af Gammelgaard, Hans Tellus Møller, var Københavner, men en dygtig og interesseret Landmand; hans Fader var en meget anset Apoteker, og hans ældste Søn, min Barndomsven, Hans Jacob, dyrkede Farmacien med saa stort Held, at han blev en af sin Stands bedste Mænd; paa Gammelgaard elskede vi at koinme; de 4 med os jævnaldrende Børn var udmærkede Legekammerater. 
En Tur til Storstaden Sonderborg, var en Oplevelse for os Drenge. Naar Gæster skulde hentes fra Damperen eller bringes tilbage til den, fik vi undertiden Lov til at følge med; og der kom mange Gæster; min Farmoder og hendes 2 ældste Døtre plejede hvert Aar at tilbringe nogle Sommermaaneder i Præstegaarden; de havde en større Bagage med og blev afhentede med 2 Vogne, hvoraf den ene blev ladet med Kufferter og Drenge, medens Honoratiores tog Plads i Wienervognen, "æ Vinnerwun", som mine Legekamerater kaldte den, da den var forsynet med Vinduer. Folkeetymologien er slet ikke saa tosset endda. Bournonvilles kom ogsaa af og til. Balletmesteren holdt ikke af at være Gæst ret mange Dage ad Gangen; hans Hustru modtog sine to første Dattersønner ved deres Ankomst til Verden, men senere blev ogsaa hun en sjælden Gæst; de boede ogsaa adskillige Aar i Udlandet. Mine Farbrødre, Søofficererne, kom jævnlig paa kortere Besøg, og der kom mange, mange flere Gæster. Slægtninge, Venner og adskillige andre, der hverken var det ene eller andet, men kom i Embedsmedfør for at inspicere Kirken, Skolen m. m. Om Sommeren var Gæsteværelserne altid fuldt optagne, ja selv om Vinteren kunde vi have langvarige, men kærkomne Tantebesøg. Saa længe min Fader levede, var hans, Præstegaard i alle Ferier fuld af Gæster, og, da den gamle Serie var uddød, kom der en ny: Sønnerne med Venner og endnu senere med Kærester, Hustruer og Børn; altid var Modtagelsen hjertelig, og aldrig blev Forældrene trætte, selv efter'at de var blevne gamle. Det var Moder en stor Sorg, at hun som Præsteenke kun i meget begrænset Maalestok kunde udøve den Gæstefrihed, 
som var en af hendes største Glæder. Men nu kom vi nok langt bort fra Sønderborg! Vor Forbindelse med Byen var nærmest forretningsmæssig; mine Forældre kendte dog Borgmester Finsens og omgikkes dem og nogle faa Officersfamilier; de kom ogsaa sammen med adskillige af Byens andre Embedsmandsfamilier, hos fælles Bekendte. For os Børn havde Sønderborg den Tiltrækning, at den var Garnisonsby; vi var glade ved at gøre personligt Bekendtskab med "den tapre Landsoldat", om hvem vi havde hørt saa meget. Adskillige af Officererne optraadte som Lærere i Byens Skoler, og i sin smukke Bog: "Erindringer fra Sønderborg og Als« fortæller Fru Bertha Hahn, at de gjorde Danskheden betydelige Tjenester ved at lade Skoleungdommen, ogsaa den kvindelige, stifte Bekendtskab med dansk Digtekunst og dansk Historie.

Indtil Efteraaret 18133 formede Livet i Tandslet Præstegaard sig som en sand Idyl. I Hjemmet, i Menigheden, i Omgangskredsen herskede Fred og Harmoni. Bekymringer og Argrelser kunde jo nok forekomme, men de glemtes hurtigt, smaa og betydningsløse, som de var; de følgende 4 Aar blev imidlertid rige paa Sorger og tunge Tilskikkelser. I Oktober 1863 døde en lille Pige, der var kommen til i 1859, og hendes 2 Aar yngre Søster fik en Hjernesygdom, hvis Følger hun aldrig helt kom over. Men de private Sorger vejede kun lidt i Sammenligning med Bekymringen for de Farer, der truede Landet; i Syden trak det op til Torden, og, da Frederik VII døde, brød Uvejret løs. Vi Børn havde faaet en patriotisk Opdragelse, men var ingenlunde opfødte $i$ 
blindt Tyskerhad; vi lærte tidlig Tysk, og i 181;4 kunde jeg baade læse og tale Sproget ganske skikkeligt; men naturligvis saa vi ikke med blide Øjne paa Slesvigholstenerne og deres Hjælpere. Fader var aldrig yderliggaaende i nogen Retning; han var altfor forstandig og adruelig til at overvurdere os selv eller undervurdere vore Modstandere, og han var ganske klar over, hivad Udfaldet af en Krig vilde blive. For os Drenge, der havde hørt saa meget om "forrige Krig“, stod Situationens Alvor ikke ganske klart; jeg vil paa ingen Maade sige, at vi glædede os, vi vidste jo godt, at en Krig vilde koste baade Blod og meget andet; men vi folte, at vi stod overfor en Oplevelse, som ikke faldt $i$ alle Drenges Lod; vi var egentlig aldrig nervøse eller overspændte endsige bange; men vi havde Øjne og Øren vidt aabne og var med over alt, hvor der var noget at se eller høre.

Kanonaden fra Mysunde 2. Februar hørtes tydeligt i Tandslet, og vore Barnehjerter svulmede af Stolthed ved Efterretningen om, at Preusserne var afviste. Vi hørte ogsaa den næste Dag, at der blev kæmpet ved Danevirke, men havde ingen rigtig Forstaaelse af Kampens Resultat; Tilbagetoget gjorde ikke noget overvaldende Indtryk paa os; det betød jo, at vi fik Begivenhederne paa nært Hold. Moder rustede sig til at modtage de ubudne Gaster, og hvad hun og Øens øvrige Kvinder præsterede i det følgende Halvaar var i Sandhed beundringsværdigt. Sine Gulvtæpper skar hun itu; de hlev lagt oven paa Halmen i de talrige Sengesteder, der blev slaaet op omkring i Udhusene; af Dyner besad hun et stort Lager, ligesaa af Lagner; 7-8 Officerer og henved en Snes Mand kunde hun huse. Men vore egne Senge 
blev ogsaa plyndrede, Ungerne stuvede sammen, et Par Stykker i hver Seng, og Pigerne pakkede ind i Fodposer. Køkken og Bryggers blev sat i krigsmæssig Stand; Præstegaarden blev et første Klasses Pensionat for en højere Stab; Brigadechefen fik "den røde Stue«, Officererne og Embedsmændene i hans Følge belagde Gæsteværelserne, Faders Stue blev Brigadekontor; Spise- og Lagligstuen var fælles for Indkvarteringen og Familien, der kun beholdt Soveværelserne til egen Raadighed. Lnder disse Omstændigheder gik det kun smaat med Undervisningen $\mathbf{i}$ Hjemmet; ogsaa Landsbyskolen var hævet og lavet om til Lazareth. Moder og hendes flinke Piger var utrættelige og vore Gæster henrykte over det udmærkede Kvarter, hvor Mand og Kone kun tænkte paa at gøre det godt for dem, der skulde hvile efter Strabadserne derovre paa Dybbøl. Jeg besidder endnu et efter den Tids Forhold pragtfuldt Album med Officersportrætter, der overraktes min Moder paa hendes Fodselsdag, den 23. Marts. De Delikatesser, der blev sendte til Officererne, blev afleverede til Moder og anvendte til fælles Bedste; der kunde vanke baade Østers og Champagne. I Begyndelsen blev den samme Stab 6 Dage hos os og afløstes saa af en anden; men senere blev Opholdet betydelig forkortet. Vi fik jævnlig Besøg af andre Officerer, og der kom Folk, der ikke var Militære, ja ikke engang Danske. Jeg mindes Italieneren Gallenga, som var Krigskorrespondent for Verdensbladet "Times«, og Franskmanden Arnout, der ogsaa var Korrespondent, samt Englænderne Herbert og Hall, et Par unge Mænd af god Familie, der optraadte som modige Ambulancesoldater. Herbert var klædt i Skind, og Soldaterne 
kaldte ham Robinson. De fremmede holdt meget af at komme hos de sprogkyndige Præstefolk og var taknemlige Tilhørere, naar Moder havde Tid til at spille for dem. Det var Kaptajn Fallesen, Det Kgl. Teaters senere Chef, der indførte de fremmede Journalister $\mathbf{i}$ vort $\mathbf{H j e m}$, som de skildrede $\mathrm{j}$ Artikler, der fandt Vej til fjerne Lande; i en australsk Avis har jeg set vor Præstegaard og dens Beboere meget udførligt og sympatisk omtalte. Der kunde være meget livligt i den store Dagligstue saadan en Aften, naar Indkvarteringen og Værtens Familie var samlede; der blev sunget og musiceret, spillet Selskabsspil eller konverseret; Drengene blev opmuntrede til Spilopper; det var en yndet Fornøjelse at faa dem til at fortælle Historier $\mathbf{i}$ alsisk Mundart. Der faldt of te noget af til os; jeg blev rigelig belønnet, da jeg havde begaaet den Niddingsdaad at trække Stolen bort fra den lille Kaptajn Marcussen, der begejstret sang en fransk Vise, hvorefter han under stærk Applaus satte sig paa Gulvet. Huset var ualmindelig stærkt belagt, da jeg fejrede min Fødselsdag, og det strommede ind med Gaver i Form af Rigsdalere og Marker. Allerede dengang lonnede det sig at være en af "Tuxens Drenge«, senere i. Livet har mange Officerer vist Venlighed mod Sønnen af de udmærkede Kvartervarter fra 1864. Naturligvis blandede der sig megen Alvor ind i Livet i Præstegaarden; mere end een Gang skete det, at der om Aftenen kom Bud om, at en eller flere af de Officerer, der nylig havde forladt os, var faldne. Dybbøls Beskydning og Sønderborgs Bombardement gjorde et uudsletteligt Indtryk; de blyindfattede Ruder i mit Soveværelse klirrede Dag og Nat; Røgen fra den brændende By for- 
mørkede Horisonten om Dagen, medens Flammerne lyste om Natten. Fra Klokketaarnet kunde man se over til Dybbøl, Vemmingbund og Broager. Naar Kolonnerne holdt Hvil i Byens Nærhed, var vi altid paa Færde, rede til at yde en Haandsrækning, skaffe Vand, og vise Vej, ganske sorn Nutidens Spejdere. Vi førte et raskt Friluftsliv; min yngste Broder, Carl, en ualmindelig køn 6-y Aars Gut, blev undertiden bortført af Ordonanserne, der satte ham foran paa Sadlen, og vi andre fik ogsaa jævnlig en rask. Ridetur, vi skøttede os selv, men kom aldrig til Fortræd. Det var Synd at sige, at Soldaterne var begejstrede for Krigen; men Modløshed mærkede jeg ikke; derimod hørte jeg tidt Beklagelser over den passive Rolle, de maatte spille, og mod "Københavnerne» var Stemningen ikke blid. Den 18. April staar tydeligt for min Erindring, Alarmsignalerne og Skydningen lyder endnu i mine Øren; jeg ser 4. Regiment samles og rykke ud; Huset blev tømt for Indkvartering; i Haven gik Fader ganske roligt og beskar sine Hindbær; senere i Livet har jeg selv erfaret, hvor beroligende Havearbejde kan virke paa et forpint Sind.

Vaabenstilstanden var en herlig Tid; Indkvarteringen var ikke trykkende, kun en Brigadestab; Chefen, Oberst Kaufmann, General de Mezas tidligere Stabschef, var tilmed fraværende det meste af Tiden; den ene af Adjutanterne var min Faders Fætter, den senere Krigsminister og Generalmajor Christian Tuxen, en dygtig, livlig og fornøjelig ung Mand; han var nygift, og der gik Bud efter den unge Frue, som var glad ved denne Form for Landliggeri. Paa Kontoret arbejdede min Faders Søstersøn, Musikeren Pe- 
der Mandrup Meyer, der senere blev en dygtig Orgelspiller og Musikpædagog; han spillede meget med Moder. Der faldt mange Ture af for os Drenge; Staben havde jo Heste nok; vi kørte til Sønderborg, saa paa de sodede Ruiner, samlede Granatstumper, besøgte Batterierne og legede i Lobegravene langs Sundet. Herfra saa vi tydeligt de preussiske Poster paa Sundevedsiden, hvis Bajonetter og blanke Knapper lynede i Solen; 50 Aar senere kom jeg dem paa endnu nærmere Hold, naar jeg inspicerede Grænsen; men dengang havde de ingen blanke Knapper, Bajonetten sad i Skeden, og Geværet var overhængt. Et andet Maal for vore Udflugter var Høruphav, hvor der herskede et broget Liv; ved Skibsbroerne laa der en Mængde Dampere, som holdt Forbindelse med de øvrige Landsdele og bragte Forsyninger til Tropperne; en af Faders Fatre, en gammel Soofficer, var ansat ved Magasinerne, hvor Varerne midlertidig blev oplagrede, indtil de kunde transporteres til deres Bestemmelsessteder. Dette skete til Dels ved $\mathrm{Hj}$ ælp af en Vognpark, hovedsagelig bestaaende af sydslesvigske Køretojer, der ufriv:lligt var fulgte med den tilbagegaaende Hrr; baade Kuskene og Hestene havde det i Begyndelsen slemt, da de ikke direkte hørte til Hæren; først efter lang Tids Forløb blev de taget ordentligt i Forplejning; men dette Træn saa ikke godt ud. En Dag saa jeg et stort Kommando Soldater komme marcherende i straalende Humør under Sang og Flojtespil; de gik om Bord i en Damper, der kastede los og lob ud af Fjorden; det var Forstærkningsmænd, der skulde hjemsendes. At det var en Kapitalfejl midt under Krigen at skille sig af med krigsvant Mandskab og erstatte det med Rekrutter, 
der var meget daarligt uddannede, begreb jeg naturligvis ikke. Gennem Øen var der udstukket Kolonneveje, der alle forte til Kegnæs Drag, den Landtange, der forbinder den langstrakte lille Halvø med Hovedøen. her var der anlagt nogle Værker, der skulde optage Als' Besætning, hivis den blev tvungen til at romme Øen, og dække dens Indskibning. Denne Befæstning gæstede vi flere Gange; jeg mindes, at den var besat med Flaadens Mandskab og bestykket med Skibskanoner; jeg lagde Mærke til at Kardæskerne saa anderledes ud end dem, jeg kendte fra Sønderborg. I det hele fik jeg meget at se og høre; jeg hjalp engang med ved Anlæget af en Felttelegraflinie, og en af Folkene sagde: "sikken en rask lille Pionér!« 8 Aar efter val" jeg det virkelig.

Kun altfor snart blev der Brug for Værkerne ved Kegnæs. Vore Statsmænd magtede ikke at udvikle Vaabenstilstanden til en brugelig Fred; Fjendtlighederne blev genoptagne, og den 29. Juni faldt Als efter et Forsvar, som trods flere glimrende Episoder kunde have varet bedre; Erobringen burde have kostet Fjenden storre Ofre. Selve Kampen saa vi intet til; de narmeste Granater faldt en halv Mils Vej fra os; 6. Regiment, der retirerede gennem Tandslet, blev ikke angrebet, og de danske Tropper slap uantastede bort. Preusserne saa vi forst den 30. Juni; jeg ser endnu Uhlanerne med spændte Karabiner forhøre min Fader.

$\mathrm{Nu}$ oprandt der en alvorlig og sørgelig Tid; ikke blot looldt Preusserne deres Indtog i Tandslet Præstegaard, der i Juli maatte huse General Mannstein efter i Juni at have modtaget General Steinmann, men vi blev hjemsøgte af svære Sygdomme. Byen havde 
rummet et Par smaa Lazaretter og havde, hvad der var endnu værre, tjent som Opholdssted for Kvartersyge, d. v. s. Soldater, som led af en lettere Daarlighed eller beredte sig paa en haard Sygdom, f. Eks. Tyfus eller Difteritis, der endnu ikke var erkendt. Disse Sygdomme greb om sig og bortrev adskillige af Befolkningen. I Præstegaarden var begge Forældre, 4 Børn, 2 Piger og 1 Karl paa en Gang i højere eller ringere Grad angrebne af Difteritis; den 8-aarige Edmond, det kraftigste af alle Børnene, bukkede under for Sygdommen; vi andre kom os; men jeg led i mange Aar af en svag Hals. Under alt dette havde vi et Par preussiske Officerer med Oppassere i Indkvartering; de var meget deltagende, men syntes ikke at tænke paa, at de selv var i Fare og deres Værter til megen Besvær. Aaret ud beholdt vi en mindre Styrke i Byen og havde stadig 1-2 Officerer i Huset. De opforte sig altid godt, der var mange fine og dannede Mand iblandt dem, der respekterede vore nationale Følelser og sagde onde Ord om Slesvigholstenerne.

Saa kom den sargelige Fred, der skilte det til national Bevidsthed vaagnede Nordslesvig fra Danmark. Alle juridiske og enkelte gejstlige Embedsmænd blev fordrevne, de, der blev tilbage, maatte iagttage stor Forsigtighed; men i al Stilhed rustede Befolkningen sig til den Kamp for Sprogets og Nationalitetens Bevarelse, som den maalbevidst og besindigt med Kraft og sejg Udholdenhed forte igennem mere end et halvt Aarhundrede. Paa os Drenge havde Krigen gjort et uudsletteligt Indtryk; vore Lege fik et krigerisk Præg, vi eksercerede og byggede Skanser, kæmpede indbyrdes og med Drengene fra andre Landsbyer. Jeg havde altid haft Lyst til at blive Officer; 
min Farfar var Officerssøn; han selv, 4 af hans Brødre. 4 af hans Sonner og flere af hans Brodersønner, havde tjent som Officerer i Flaade og Hær; han selv og adskillige af de andre havde udmerket sig i det 19. Aarhundredes Krige; det var ikke saa underligt, at jeg og min yngre Broder, Carl, vilde gaa samme Vej; saa kunde vi maaske faa Lov til at være med til at tage Hævn over Preusserne, hvis Ondskab mod Danmark sikkert ikke vilde gaa ustraffet hen. Vi gennemforte ogsaa begge vor Plan, og i 1871 blev vi antagne til Krigstjeneste. Vi oplevede Preussernes Nederlag, men kom ikke til at yde aktiv Bistand dertil. Længe varede det, inden Hævnens Time kom; da Preussen og Østerrig i $1866 \mathrm{kom}$ op at slaas om Byttet, blussede Haabet op, og, skønt Preusserne blev Sejrherrer, kom Fredstraktaten dog til at indeholde en Lofteparagraf, som vi var naive nok til at vente os noget af. Senere kom det klart nok for Dagen, at Preussens Politik overfor Danmark i Aarene efter Krigen kun var Kattens Leg med Musen; Pragerfredens $\S 5$ var kun en "Film", som man nu vilde sige. Det nationale Spørgsmaal spillede for os Drenge en Hovedrolle; naar vi anlagde danske Kokarder, sang danske Nationalsange og anbragte de danske Farver, hvor de var slettede, var det ikke rene Drengestreger; vi var Danske i langt højere Grad end Kongerigets Beboere, og da vi selv kom til at høre til dem, kunde vi ikke begribe, at det sønderjyske Spørgsmaal fandt saa ringe Interesse og saa liden Forstaaelse hos vore unge Kammerater.

i de første Aar efter Krigen blev de større Drenge af vor Omgangskreds sendte til kongeriske Skoler; mange af de unge Karle forlod det afstaaede Land, 
Lviljen mod at blive preussiske Soldater var uhyre stor. Undervisningen i Hjemmet, der i Krigsaaret havde staaet i Stampe, blev genoptaget med Kraft; jeg begriber ikke, hvorledes mine Forældre kunde overkomme at give de mange Timer. Egentlige Ferier havde vi ikke; men af og til blev der givet en eller flere Fridage, naar der var særlig Grund dertil. Vi klyngede os stadig fastere til Hjemmet og tænkte med sorg paa, at vi snart skulde forlade det; i 1866 blev det bestemt, at jeg skulde i en rigtig Skole efter Sommerferien; jeg vilde helst til Sorø, hvor næsten alle de andre Alsingere blev anbragte; men, da mine BedsteforæIdre boede paa Fredensborg, kom jeg i Frederiksborg Latinskole, som kun laa en Mil fra deres Hjem. Den 18. August forlod jeg med Sorg i Sinde mit Barndomshjem; Afskeden fra Forældre og Soskende, Folkene, Vennerne, Heste og Køer, alle de levende Væsner og livløse Ting, jeg i henved 14 Aar havde levet imellem, var sønderrivende, jeg tudbrolede, da jeg fra Damperen saa Lysabild Kirke forsvinde under Horisonten; som saa mangen anden Alsinger, der forlod sin elskede Fødeø, hulkede jeg: "Lysabild Kirk, Lysabild Kirk, no sier æ dæ aalle bat «.

I lange Tider led jeg umaadeligt af Hjemvé. Mine Breve til Forældre, Brødre og Venner aander Længsel efter atter at færdes mellem dem. Mine nye Kammerater, mit nye Hjem, som jeg senere kom til at holde meget af, tiltalte mig slet ikke; Præstegaardsmarkerne forekom mig langt smukkere end Frederiksborgs og Fredensborgs Slotshaver; jeg gik helst alene paa Markerne bag Byen og kunde ikke lide de andre Drenge, der gjorde Nar ad min alsiske 
Dialekt og mit hjemmelavede Tøj. I Juleferien gensaa jeg mit Barndomshjem; baade Hen- og Hjemrejsen var uhyre besværlige og langvarige; endnu engang maatte jeg prove Afskedens Bitterhed; men (det blev ogsaa den sidste. Kort efter min Afrejse nægtede Fader at aflagge Ed til Landets Herre; den 31. Maj fik han sin Afsked, og den 25. Juni forlod han og de 2 Drenge Tandslet Prastegaard, som Moder med sine Smaapiger, hvoraf en var født i 1865, havde maattet forlade en Maaned forinden. Kun 3 Dage efter Bortrejsen fik Fader Embedet som Sognepræst i Esbønderup og Nøddebo, der kun laa et Par smaa Mil fra Frederiksborg; vi fik atter et Hjem med Mark og Have, Heste og Køer m. m.; men for os Drenge, der aldrig kom til at bo der, blev det kun et Feriehjem, hvor vi i korte Tidsrum kunde leve et lykkeligt Familieliv i naturskonne Omgivelser; mange gode Minder har jeg derfra; men Sognets Beboere blev mig altid fremmede, og, naar jeg en sjælden Gang kommer dertil, besøger jeg kun de døde. I henved 25 Aar boede mine Forældre i Esbønderup Prastegaard; men den Tid, de havde tilbragt $\mathbf{i}$ Tandslet, stod altid for dem som den lykkeligste Del af deres Liv; de elskede at opfriske Minderne derfra, rejste flere Gange derover og modtog endnu hyppigere Gæster derfra eller fra andre Dele af Øen. Jeg sørgede dybt og længe, da det blev afgjort, at jeg fremtidig kun skulde gense Tandslet som Gast; men mine, Besøg blev mig dog til stor Glaede. Som nybagt Student tilbragte jeg min Sommerferie paa Als, og senere kom jeg ret jævnligt derover; paa forskellig Maade vedligeholdtes Forbindelsen ogsaa efter 1902, da jeg — som jeg troede — for sidste Gang besøgte 
mit Barndomshjem; det var blevet utaaleligt at se, hvor fast og trygt Erobreren havde sat sig til rette $i$ det gamle danske Land.

Men Afskeden blev ikke endelig; i 1918 indtraf det store Under: Tyskland blev nødsaget til at bede om Fred, og der blev Udsigt til, at mit Barndomshjem atter kunde blive dansk. I Februar 1920 havde vi gamle udvandrede eller fordrevne Alsingere den store Oplevelse at blive kaldt over for at stemme om vor Fødestavns Fremtidsskæbne. Overrejsen var uforglemmelig; paa skibene traf gamle Bekendte hinanden efter mange Aars Adskillelse, alle gode Følelser vaagnede; i en Stemning, der ikke lader sig beskrive, stod vi i Vintereftermiddagens dæmpede Belysning ind i Alssund; fra mange Huse i Sønderborg vajede Dannebrog, fra adskillige ogsaa det tyske Flag; men oppe fra Kasernens Tag smældede Trikoloren og lovede, at de tyske Farver snart skulde forsvinde. Da jeg efter en festlig Uge sejlede tilbage til Sjælland og saa Lysabild Kirke svinde bag Horisonten, bød jeg den et muntert: "paa Gensyn!" Adskillige Gange har jeg siden set det hvide Taarn dukke frem og hilst det med Glæde; saa længe, jeg endnu har Kræfter dertil, vil jeg vedligeholde Forbindelsen med den "Plet af Jord, hvor Livets Stemme steg første Gang af spæde Bryst«. 